\title{
Erratum: Sensitive mutation detection in heterogeneous cancer specimens by massively parallel picoliter reactor sequencing
}

R K Thomas, E Nickerson, J F Simons, P A Jänne, T Tengs, Y Yuza, L A Garraway, T LaFramboise, J C Lee, K Shah, K O’Neill, H Sasaki, N Lindeman, K-K Wong, A M Borras, E J Gutmann, K H Dragnev, R DeBiasi, T-H Chen, K A Glatt, H Greulich, B Desany, C K Lubeski, W Brockman, P Alvarez, S K Hutchison, J H Leamon, M T Ronan, G S Turenchalk, M Egholm, W R Sellers, J M Rothberg \& M Meyerson Nat. Med. 12, 852-855 (2006); published online 25 June; corrected after print 13 September 2006

In the version of this article initially published, it should have been acknowledged that Jan F. Simons, in addition to Roman K. Thomas and Elizabeth

Nickerson, contributed equally to this work. The error has been corrected in the HTML and PDF versions of the article.

\section{Corrigendum: Nogo-A-specific antibody treatment enhances sprouting and functional recovery after cervical lesion in adult primates.}

P Freund, E Schmidlin, T Wannier, J Bloch, A Mir, M E Schwab \& E M Rouiller

Nat. Med. 12, 790-792 (2006); published online 2 July 2006; corrected after print 13 September 2006

In the version of this article initially published, the cut corticospinal tract (CST) stumps rostral to the lesion site in Figure 2d and Supplementary Figure 3a online were meant to be represented schematically, a fact not explained in the figure legend. These representations should therefore have been replaced by full camera lucida reconstructions of these rostral cut CST stumps for the corresponding animals, requiring the consideration of additional sections of the spinal cord located more laterally than those drawn here for the reconstruction of the CST axonal arbors caudal to the lesion (sections for which the contours are represented here). The figure has been corrected in the HTML and the PDF versions of the article.

d

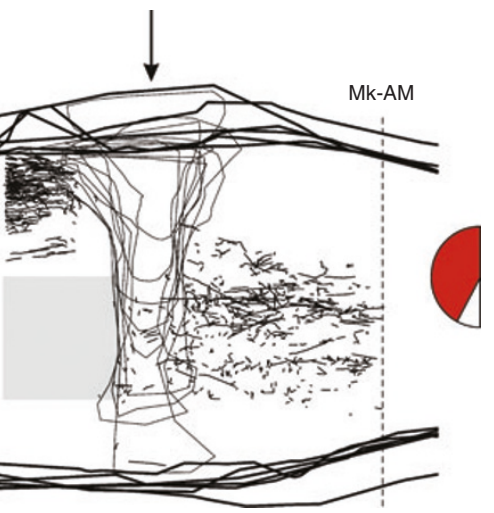

